\title{
Evaluasi Tingkat Penerimaan Masyarakat terhadap Aplikasi Jogja Istimewa menggunakan Modifikasi Unified Theory of Acceptance and Use of Technology 2 (UTAUT2)
}

\author{
Nurviyanto Widya Nugroho ${ }^{1}$, Wing Wahyu Winarno ${ }^{2}$, Hanson Prihantoro Putro ${ }^{3}$ \\ ${ }^{1}$ Universitas Islam Indonesia \\ ${ }^{2}$ Sekolah Tinggi Ilmu Ekonomi YKPN \\ ${ }^{3}$ Universitas Islam Indonesia \\ ${ }^{1}$ nurviyantonugroho@gmail.com, ${ }^{2}$ wing@ stieykpn.ac.id, ${ }^{3}$ hanson@ uii.ac.id
}

\begin{abstract}
ABSTRAK. Pemda DIY meluncurkan sistem informasi pemandu wisatawan dan lokal bernama aplikasi Jogja Istimewa. Berbeda dengan sistem informasi wisatawan dan lokal pada umumnya, aplikasi Jogja Istimewa ini di dalamnya terdapat layanan-layanan e-government. Tujuannya untuk memudahkan masyarakat mendapatkan akses informasi seputar DIY dan pelayanan publik di DIY. Sejak diluncurkan pada September 2015, mayoritas masyarakat DIY masih belum mengunduhnya. Penelitian ini akan mengevaluasi tingkat penerimaan masyarakat terhadap aplikasi Jogja Istimewa dan faktor-faktor apa aja yang mempengaruhi penerimaannya. Penelitian ini menggunakan modifikasi UTAUT2 dengan menambah variabel Trust dan Perceived Risk. Data dikumpulkan melalui penyebaran kuesioner secara online menggunakan google form ke 184 pengguna. Metode analisis data dalam penelitian ini menggunakan SEM-PLS dan menggunakan software SmartPLS. Hasilnya, tingkat penerimaan masyarakat terhadap aplikasi Jogja Istimewa masuk dalam kategori cukup baik. Diketahui, bahwa UB dipengaruhi oleh BI, HA dan FC. Sementara BI dipengaruhi oleh HA, PR, SI, TR dan PE namun tidak dipengaruhi oleh FC dan EE.
\end{abstract}

Kata Kunci: Aplikasi Jogja Istimewa; e-Government; Tingkat Penerimaan Masyarakat; UTAUT2; SEM

\begin{abstract}
The DIY government launches a traveler and local guides information system named Jogja Istimewa app. Unlike travel \& local apps in general, this Jogja Istimewa app includes e-government services. The purpose of this Jogja Istimewa app is to make it easier for citizen to get access to information about DIY and public services in DIY. Since its launch in September 2015, the majority of people in DIY have not yet downloaded it. This study will evaluate the level of citizen' acceptance towards the Jogja Istimewa app and what factors influence their acceptance. This study uses a modified UTAUT2 by adding Trust and Perceived Risk variables. Data was collected by distributing questionnaires online using google form to 184 users. The data analysis method in this study uses SEM-PLS and uses SmartPLS software. As a result, the level of citizen' acceptance of the Jogja Istimewa app is quite good. It is known, that UB is influenced by BI, HA and FC. While BI is influenced by HA, PR, SI, TR and PE but it is not affected by FC and EE.
\end{abstract}

Keywords: Jogja Istimewa app; e-Government; Citizen'Level of Aceeptance; UTAUT2; SEM

\section{PENDAHULUAN}

Pemda Daerah Istimewa Yogyakarta (DIY) menerapkan konsep Jogja Smart Province (JSP) dengan meluncurkan sistem informasi pemandu wisatawan dan lokal yaitu aplikasi Jogja Istimewa. Tujuan dari dikembangkannya aplikasi Jogja Istimewa ini adalah untuk memudahkan masyarakat dalam mendapatkan akses informasi seputar DIY dan pelayanan publik di DIY. Dengan mobile app ini, pengguna akan bisa menghindari kemacetan jika akan bepergian karena aplikasi ini menyediakan fitur CCTV sehingga pengguna bisa melihat kondisi sebenarnya dari jalan yang akan dilaluinya. Uniknya, aplikasi Jogja Istimewa ini menyediakan fasilitas bagi masyarakatnya dengan menyertakan layanan-layanan e-government sehingga memungkinkan masyarakat untuk berinteraksi dengan pemerintahnya, yang ditunjukkan dengan adanya fitur E-Lapor dan fitur permohonan informasi publik dalam menu layanan publik (PPID Yogyakarta). Dua fitur ini memungkinkan masyarakat untuk tidak perlu ke tempat dinas-dinas pemerintah terkait kalau urusannya memang bisa diselesaikan hanya melalui online.

Namun, dari sejak diluncurkannya aplikasi ini (23 September 2015) hingga saat ini, mayoritas masyararakat DIY masih belum mengunduhnya, hanya diunduh sebanyak 100.000 kali di Google Play Store. Memang, berdasarkan penelitian dari Rachmawati et al. (2018), sebanyak $92 \%$ dari 60 orang yang berasal dari pihak pemerintah, instansi penyedia aplikasi, pihak swasta, akademisi dan masyarakat menyebutkan bahwa mereka tidak mengetahui adanya aplikasi Jogja Istimewa dan hanya $8 \%$ yang mengetahuinya. Namun, penelitian dari Rachmawati et al. (2018) juga mengungkapkan walaupun sebanyak 8\% responden sudah mengetahui, sebanyak $100 \%$ dari mereka tetap tidak memanfaatkan aplikasi Jogja Istimewa dengan alasan responden belum membutuhkan dan sudah mengetahui informasi seputar DIY. Hal ini mengindikasikan 
bahwa, meskipun masyarakat sudah mengetahui adanya aplikasi Jogja Istimewa, masyarakat tetap tidak memanfaatkan/mengunduh aplikasi Jogja Istimewa.

Karena itulah, perlu dilakukan evaluasi terhadap aplikasi Jogja Istimewa dari sisi penerimaan penggunanya/masyarakatnya. Hasil dari evaluasi ini akan memudahkan pembuat kebijakan untuk meningkatkan tingkat penerimaan masyarakat terhadap aplikasi Jogja Istimewa sehingga jumlah unduhannya pun akan meningkat. Jumlah unduhannya harus ditingkatkan, karena jika tidak maka aplikasi ini akan bisa ditinggalkan oleh penggunanya. Jika itu sampai terjadi, maka aplikasi ini berpotensi untuk gagal. Gagalnya aplikasi ini tidak hanya akan merugikan Pemda DIY selaku pembuat kebijakan, tapi juga masyarakat, karena anggaran untuk mengembangkan aplikasi Jogja Istimewa juga berasal dari masyarakatnya. Jangan sampai aplikasi Jogja Istimewa ini mengalami nasib yang sama dengan aplikasi "Hi Bandung". Aplikasi "Hi Bandung" merupakan aplikasi yang dikembangkan oleh Telkom IDeC dan diluncurkan pada tahun 2013 dengan tujuan untuk menunjang penerapan Bandung Smart City 2015 (Plimbi Editor, 2015). Mirip dengan aplikasi Jogja Istimewa, aplikasi "Hi Bandung" ini juga merupakan sistem informasi travel \& local yang menawarkan kemudahan bagi masyarakat untuk memperoleh informasi seperti objek wisata, hotel, pusat perbelanjaan, restoran, layanan kesahatan, informasi perbankan, dan layanan transportasi. Namun, aplikasi ini kurang diterima di masyarakat yang ditandai dengan minimnya masyarakat yang mengunduh aplikasi ini. Jumlah unduhan yang sedikit ini akan menyebabkan aplikasi ini menjadi semakin ditinggalkan sehingga bisa mengakibatkan gagalnya aplikasi ini. Buktinya saat ini, aplikasi ini sudah tidak tersedia baik di PlayStore maupun di AppStore.

Penelitian ini akan menggunakan Unified Theory of Acceptance and Use of Technology 2 (UTAUT2) karena alasan-alasan berikut. Pertama, UTAUT2 mengintegrasikan beberapa konstruk dari model-model penerimaan pengguna sebelumnya sehingga mengurangi kekurangannya. Kedua, penggunaan aplikasi Jogja Istimewa dilakukan secara sukarela (voluntary) dan menurut Chirara (2018), UTAUT2 merupakan model yang paling komprehensif untuk pengaturan konsumen pada penggunaan teknologi digital yang dilakukan secara sukarela. Tidak seperti Technology Acceptance Model (TAM), TAM2, TAM3 dan UTAUT (model asli) yang pada dasarnya dibangun dalam konteks lingkungan kerja, di mana biaya teknologi digital dibayar oleh perusahaan sehingga para staffnya diwajibkan untuk menggunakan teknologi baru tersebut (mandatory). Ketiga, UTAUT2 menyertakan Habit (HA) penggunaan teknologi digital, yang menurut peneliti merupakan faktor penting yang mempengaruhi perilaku penggunaan warga terhadap aplikasi Jogja Istimewa. Teknologi digital semakin cepat berubah dan kebiasaan (Habit) yang dibentuk menggunakan teknologi digital sebelumnya dapat memberikan petunjuk yang membantu warga untuk menggunakan layanan baru dari publik digital dengan mudah. Terakhir, UTAUT2 menjelaskan bahwa perilaku penggunaan warga terhadap aplikasi Jogja Istimewa dipengaruhi oleh Facilitating Condition (FC) yang mencakup sumber daya dan dukungandukungan yang tersedia. Peneliti menganggap bahwa FC dapat mengurangi rasa cemas warga terkait dengan penggunaan teknologi digital, sehingga dapat meningkatkan kepercayaan diri warga untuk mencoba inovasi teknologi yang belum dikenal. Karena itulah, model UTAUT2 sebagai landasan teori secara konseptual dan praktis lebih efektif dan berguna (Singh et al., 2020).

\section{KAJIAN TEORI DAN PENGEMBANGAN HIPOTESIS}

\subsection{Unified Theory of Acceptance and Use of Technology 2 (UTAUT2)}

Venkatesh et al. (2012) mengembangkan UTAUT2 dengan mengintegrasikan konstruk-konstruk dominan dari berbagai model yang berlaku untuk mengukur perilaku pengguna terhadap penggunaan/adopsi teknologi. Model UTAUT menggunakan empat (4) konstruk utama: yaitu Performance Expectancy (PE), Effort Expectancy (EE), Facilitating Conditions (FC), dan Social Influence (SI). Sementara Venkatesh et al. (2012), membangun UTAUT2 dengan menambah tiga (3) faktor lagi dalam model UTAUT yaitu Hedonic Motivation (HM), Price Value (PV) dan Habit (HA). Perluasan tersebut menurut Singh et al. (2020), telah membawa peningkatan subtansial dalam mengukur niat perilaku dari pengguna.

Penelitian ini menggunakan UTAUT2 dengan tidak menggunakan dua (2) konstruknya, yaitu HM dan PV. Menurut Syamsudin et al. (2018), HM biasanya digunakan untuk aktivitas-aktivitas bisnis, bukan layanan e-government karena layanan e-government berhubungan dengan layanan publik. Aplikasi Jogja Istimewa tidak menawarkan aktivitas-aktivitas bagi warganya untuk berbisnis, melainkan hanya berperan sebagai media pemandu destinasi dan pelayanan publik. Penelitian terdahulu banyak yang menghilangkan variabel ini (e.g.(Alharbi et al., 2017; Lian, 2015; Munyoka, 2019; Syamsudin et al., 2018)). Sementara itu, PV didefinisikan oleh Venkatesh et al. (2012), sebagai biaya yang harus dikeluarkan untuk menggunakan sistem. Aplikasi Jogja Istimewa sendiri merupakan aplikasi yang gratis baik dalam mengunduhnya ataupun menggunakannya, jadi biaya akses internet bukanlah masalah. Peneliti-peneliti terdahulu juga banyak yang tidak menggunakan variabel PV (e.g.(Alharbi et al., 2017; Lian, 2015; Sawalha et al., 2019)). Selain dua (2) 
konstruk tersebut, variabel moderasi yang ada pada UTAUT2 yaitu age, gender, experience juga tidak disertakan dalam model penelitian yang digunakan. Hal itu dikarenakan, fokus dari penelitian ini adalah untuk mengevaluasi penerimaan masyarakat pada aspek umum terhadap aplikasi Jogja Istimewa, tanpa melihat age, gender dan experience. Disamping itu, Alharbi et al. (2017) juga menjelaskan bahwa variabel moderasi tersebut merupakan variabel-variabel yang digunakan untuk penelitian adopsi awal. Ini tentu berbeda konteksnya karena responden di penelitian ini merupakan warga yang sudah menjadi pengguna aplikasi Jogja Istimewa, bukan calon pengguna. Terlebih lagi, studi-studi terbaru dalam konteks layanan e-government juga tidak menyertakan variabel-variabel ini (e.g.(Alharbi et al., 2017; Krishnaraju et al., 2013; Venkatesh et al., 2011)).

Selain menghapus dua (2) konstruk dan variabel moderasi, penelitian ini juga menambahkan 2 variabel yaitu Trust (TR) dan Perceived Risk (PR). TR dianggap mempunyai peran yang sangat penting yang mempengaruhi pengguna untuk mengadopsi sistem (e.g.(Alharbi et al., 2017; Carter et al., 2011; Carter \& Bélanger, 2005)). Maka dari itu, variabel Trust akan disertakan dalam model penelitian ini. Sementara itu, Perceived Risk didefinisikan sebagai penilaian pribadi dari kemungkinan sebuah hasil mengecewakan yang signifikan (Robert et al., 2009). Dashti et al. (2009) menyatakan bahwa agar Trust menjadi relevan, Perceived Risk juga harus disajikan karena dasar dari sebuah kepercayaan adalah kerentanan. Meskipun tidak ada kesepakatan manakah yang lebih dulu (apakah TR mempengaruhi PR atau sebaliknya), diketahui bahwa keduanya memiliki berdampak pada niat perilaku untuk melakukan transaksi online. Beberapa peneliti sebelumnya yang juga menggunakan Perceived Risk pada konteks layanan e-government (e.g.(Carter et al., 2016; Chatzoglou et al., 2015; Dashti et al., 2009; Lian, 2015)).

Jenis-jenis risiko sendiri sangat beragam tergantung dari produk dan layanannya (Chatzoglou et al., 2015). Dalam penelitian Chatzoglou et al. (2015) mengenai adopsi layanan e-government, mereka memeriksa 5 jenis-jenis resiko yaitu Security/Privacy Risk, didefinisikan sebagai risiko kehilangan data pribadi yang sensitif selama transaksi. Kedua, Financial Risk, didefinisikan sebagai risiko ekonomi karena kesalahan transaksi atau penyalahgunaan informasi pengguna sehingga mengakibatkan ketakutan untuk bertransaksi. Ketiga, Social Risk, Ini mengacu pada kemungkinan yang menggunakan sistem dapat mengakibatkan ketidaksetujuan teman / keluarga / rekan kerja (Lee, 2009) sehingga itu dapat memprovokasi penilaian negatif terhadap pengguna tersebut (Chatzoglou et al., 2015). Ketiga, Time/Convience Risk, merujuk pada risiko hilangnya waktu dan ketidaknyamanan pengguna yang terjadi karena keterlambatan transaksi yang disebabkan proses loading yang lama atau antarmuka sistem yang membingungkan. Keempat, Performance Risk, Ini mengacu pada kerugian yang ditimbulkan karena sistem tidak bekerja sebagaimana mestinya. Lima (5) jenis risiko tersebut dianggap oleh Chatzoglou et al. (2015) dapat mewakili pengukuran dari variabel PR. Peneliti juga beranggapan bahwa lima (5) jenis-jenis risiko tersebut juga cocok untuk disertakan untuk mengukur Perceived Risk yang merupakan salah satu faktor yang mempengaruhi penerimaan pengguna terhadap aplikasi Jogja Istimewa. Oleh karena itu, lima (5) jenis-jenis tersebut akan disertakan dalam penelitian ini sebagai indikator untuk mengukur varibel PR.

\section{a. Performance Expectancy (PE)}

PE didefinisikan sebagai sejauh mana seseorang percaya bahwa menggunakan sistem akan membantunya dalam melakukan aktivitas-aktivitas tertentu (Venkatesh et al., 2012). Beberapa peneliti-peneliti sebelumnya yang menggunakan UTAUT asli maupun UTAUT2 membuktikan bahwa PE punya pengaruh yang positif terhadap niat perilaku penduduk untuk menggunakan layanan e-government (e.g.(Alharbi et al., 2017; Chirara, 2018; Sawalha et al., 2019)).

Berdasarkan uraian di atas, maka diajukan hipotesis sebagai berikut:

H1: Performance Expectancy (PE) berpengaruh positif terhadap Behavior Intention (BI)

\section{b. Effort Expectancy (EE)}

$\mathrm{EE}$ adalah tingkat kemudahan yang terkait dengan penggunaan teknologi oleh konsumen (Venkatesh et al., 2012). Beberapa penelitian sebelumnya yang menggunakan UTAUT2 membuktikan bahwa EE punya pengaruh yang signifikan terhadap BI untuk menggunakan layanan e-government (e.g.(Chirara, 2018; Lian, 2015; Sawalha et al., 2019; Syamsudin et al., 2018)).

Berdasarkan uraian di atas, maka hipotesis yang diajukan yaitu:

H2: Effort Expectancy (EE) berpengaruh positif terhadap Behavior Intention (BI)

\section{c. Social Influence (SI)}

Social influence (SI) adalah sejauh mana seseorang menganggap orang lain yang dianggap penting baginya percaya bahwa dia harus menggunakan sistem tertentu (Venkatesh et al., 2003). Beberapa penelitian sebelumnya yang menggunakan UTAUT UTAUT2 membuktikan bahwa SI punya pengaruh yang signifikan 
terhadap BI warga untuk menggunakan layanan e-government (e.g.( Alharbi et al., 2017; Chirara, 2018; Lian, 2015; Sawalha et al., 2019)).

Berdasarkan uraian di atas, maka diajukan hipotesis sebagai berikut:

H3: Social Influence (SI) berpengaruh positif terhadap Behavior Intention (BI)

\section{d. Facilitating Conditions (FC)}

Pada UTAUT2, Venkatesh et al. (2012) menjelaskan bahwa ketika FC dimoderasi oleh jenis kelamin dan usia, FC tidak hanya mempengaruhi UB tapi juga mempengaruhi BI. FC itu sendiri didefinisikan sebagai faktor yang merujuk pada persepsi konsumen tentang sumber daya dan dukungan yang tersedia untuk melakukan perilaku (Venkatesh et al., 2012). Beberapa peneltian sebelumnya telah membuktikan bahwa FC mempunyai pengaruh yang signifikan terhadap BI warga untuk menggunakan layanan e-government (Al Mansoori et al., 2018; Alharbi et al., 2017; Lallmahomed et al., 2017).

Berdasarkan uraian di atas, maka diajukan dua (2) hipotesis sebagai berikut:

H4: Facilitating Conditions (FC) berpengaruh positif terhadap Behavior Intention (BI)

H5: Facilitating Conditions (FC) berpengaruh positif terhadap Use Behavior (UB)

\section{e. Habit (HA)}

Dalam UTAUT2, Venkatesh et al. (2012) menjelaskan bahwa HA dapat mempengaruhi BI maupun juga UB. Dijelaskan bahwa Habit adalah sejauh mana seseorang cenderung melakukan perilaku secara otomotasi karena proses belajar (Venkatesh et al., 2012). Penelitian yang menggunakan HA dalam konteks e-government menunjukkan bahwa HA memang mempunyai pengaruh yang signifikan baik terhadap BI (Alharbi et al., 2017; Syamsudin et al., 2018) maupun UB (Chirara, 2018).

Berdasarkan uraian di atas, maka diajukan dua (2) hipotesis sebagai berikut:

H6: Habit (HA) berpengaruh positif terhadap Behavior Intention (BI)

H7: Habit (HA) berpengaruh positif terhadap Use Behavior (UB)

\section{f. $\quad$ Trust (TR)}

Trust (kepercayaan) pada e-government didefinisikan sebagai keinginan individu atau kelompok untuk menjadi rentan dan bergantung pada janji-janji lembaga pemerintah yang menyediakan layanan elektronik (Mayer et al., 1995; Mcknight et al., 2002). Banyak penelitian telah menyoroti pentingnya kepercayaan dalam penerimaan teknologi baru dan telah mengidentifikasi kepercayaan sebagai faktor prediktor penting dari BI untuk menggunakan layanan e-government (e.g.(Albesher, 2016; Lian, 2015; Shareef et al., 2011; Weerakkody et al., 2013)).

Berdasarkan uraian di atas, maka diajukan hipotesis sebagai berikut:

H8: Trust (TR) berpengaruh positif terhadap Behavior Intention (BI)

\section{g. Perceived Risk (PR)}

Perceived Risk (PR) didefinisikan sebagai penilaian pribadi dari kemungkinan sebuah hasil mengecewakan yang signifikan (Robert et al., 2009). Seperti yang sudah dijelaskan sebelumnya, penelitian ini akan memeriksa lima (5) jenis resiko yang berasal dari penelitian Chatzoglou et al. (2015) yang tentunya disesuaikan dengan konteks aplikasi Jogja Istimewa. Dikarenakan fitur yang melibatkan identitas hanya terdapat pada fitur pengajuan permohonan informasi publik (dalam menu PPID Yogyakarta) dan E-Lapor, maka tentunya tidak semua penggunanya menggunakan kedua fitur ini. Sehingga, agar indikator security/privacy risk ini dapat diukur dengan baik, maka akan ditambah pertanyaan khusus pada pengisian karakteristik responden. Pertanyaannya adalah "Pernahkah anda mengajukan permohonan informasi publik pada aplikasi Jogja Istimewa atau menggunakan fitur E-Lapor?”. Hal yang sama juga berlaku pada indikator Financial Risk karena fitur yang melibatkan transaksi uang hanya terdapat pada fitur E-Ticketing. Pertanyaannya adalah "Pernahkah anda menggunakan fitur E-Ticketing?". Beberapa penelitian sebelumnya banyak yang membuktikan bahwa PR mempunyai pengaruh yang negatif terhadap BI (e.g.(Aljazzaf, 2019; Carter et al., 2016; Chatzoglou et al., 2015; Dashti et al., 2009; Lian, 2015)).

Berdasarkan uraian di atas, maka diajukan hipotesis sebagai berikut:

H9: Perceived Risk (PR) berpengaruh negatif terhadap Behavior Intention (BI)

\section{h. Behavior Intention (BI)}

Behavior Intention (BI) didefinisikan sebagai niat pelanggan untuk mengadopsi dan memanfaatkan alat tertentu di masa depan (Ajzen, 1991; Taylor \& Todd, 1995; Venkatesh et al., 2003). Ajzen (1991) menyatakan bahwa BI merupakan penentu terdekat dari perilaku dan menyetujui bahwa BI memiliki pengaruh langsung 
pada adopsi. Penelitian pada konteks e-government telah menunjukkan bahwa BI mempengaruhi UB (e.g.(Al Mansoori et al., 2018; Chirara, 2018; Rabaa'i, 2017)).

Berdasarkan uraian di atas, maka diajukan hipotesis sebagai berikut:

H10: Behavior Intention (BI) berpengaruh positif terhadap Use Behavior (UB)

\section{METODOLOGI PENELITIAN}

\subsection{Populasi dan Sampel}

Populasi yang digunakan dalam penelitian ini yaitu pengguna Jogja Istimewa yang sedang tinggal di DIY, baik itu warga asli DIY maupun warga perantauan yang sedang tinggal di DIY. Perantau yang dimaksud juga tidak hanya bagi yang tinggal menetap di DIY, namun juga menyertakan perantau yang tinggal sementara di DIY (misalnya kos). Dari usia, karakteristik respondennya yaitu masyarakat yang berumur 20-59 tahun. Lalu dari latar belakang pekerjaan, penelitian ini menyertakan semua kalangan baik itu yang sudah bekerja maupun yang belum.

Teknik analisis datanya menggunakan Structural Equation Modelling (SEM), sehingga ukuran sampelnya juga harus memenuhi ukuran sampel minimal untuk penerapan model SEM. Hair et al. (1998) menyarankan ukuran sampel minimal untuk analisis SEM adalah 100 sampai 200. Sementara Bentler \& Chou (1987) menyarankan bahwa paling rendah rasio lima (5) responden per variabel manifest/variabel teramati/indikator akan mencukupi untuk distribusi normal ketika sebuah variabel laten mempunyai beberapa indikator. Dalam penelitian ini terdapat 32 variabel manifest, jadi jumlah sampel minimum yang dibutuhkan adalah sebanyak $160(5 \times 32=160)$. Untuk teknik pengambilan sampelnya yaitu non probability atau memungkinkan setiap anggota populasi tidak mempunyai peluang yang dapat dipilih sebagai objek penelitian (Martono, 2010) dan pemilihan respondennya menggunakan convenience sampling yang berarti informasi diambil dari anggota populasi yang bersedia untuk mengisi kuesioner (Sekaran \& Bougie, 2006).

\subsection{Teknik Penggumpulan Data}

Pada saat pengumpulan data dilakukan sedang terjadi pandemi Coronavirus Disease 2019 (Covid-19), sehingga penelitian ini hanya akan menyebarkan kuesioner secara online melalui Google Form. Kuesioner tersebut menggunakan pertanyaan tertutup. Penilaian kuesionernya menggunakan skala Likert yang bernilai 1 hingga 6 dengan kriteria 1=Sangat Tidak Setuju, 2=Tidak Setuju, 3=Agak Tidak Setuju, 4=Agak Setuju, 5= Setuju, dan 6= Sangat Setuju.

\subsection{Teknik Analisis Data}

Untuk menguji hipotesis, penelitian ini menggunakan analisa kuantitatif. Analisis data akan menggunakan pendekatan variance based SEM atau pendekatan Partial Least Square (PLS) dengan bantuan aplikasi Smart-PLS 3.0. Penelitian ini menggunakan SEM untuk tujuan prediksi sehingga PLS lebih cocok untuk digunakan jika dibandingkan dengan metode covariance based karena Abdillah \& Hartono (2015) menyatakan bahwa teknik statistik variance based SEM merupakan pilihan yang tepat untuk menguji pengaruh antar variabel dengan tujuan untuk memprediksi hubungan sebab-akibat pada level konstruk atau variabel. Evaluasi model pada SEM terdiri dari dua tahap, yakni evaluasi outer model dan evaluasi inner model.

Tabel 1. Tahap Pengujian Outer Model

\begin{tabular}{|c|c|c|c|c|c|}
\hline Tahapan & & Jenis Pengukuran & & Syarat & Sumber \\
\hline Uji Validitas & $>$ & Loading factor & $>$ & $>0,7$ & $>\quad($ Chin, 1998) \\
\hline Konvergen & $>$ & Nilai AVE & $>$ & $>0,5$ & $>$ Fornell \& Larcker (1981) \\
\hline $\begin{array}{l}\text { Uji Validitas } \\
\text { Diskriminan }\end{array}$ & $>$ & $\begin{array}{l}\text { Nilai akar Kuadrat } \\
\text { AVE } \\
\text { Nilai cross loading }\end{array}$ & $>$ & $\begin{array}{l}\text { Nilai akar Kuadrat AVE } \\
\text { lebih besar daripada nilai } \\
\text { korelasi antar konstruk } \\
>0,7\end{array}$ & $\begin{array}{ll}> & (\text { Ghozali, 2006) } \\
> & (\text { Fornell \& Larcker, 1981) }\end{array}$ \\
\hline Uji & $>$ & Composite reliability & $>$ & $>0,7$ & $>\quad$ (Ghozali, 2006) \\
\hline Reliabilitas & $>$ & Cronbach's alpha & $>$ & $>0,6$ & $>\quad$ (Ghozali \& Latan, 2015) \\
\hline
\end{tabular}

Uji Inner model dapat dilakukan dengan uji $R$-Square untuk mendapatkan informasi tentang seberapa besar kontribusi variabel independen dalam mempengaruhi variabel dependen (Ghozali, 2007). Kemudian uji $\mathrm{t}$, dilakukan untuk mengetahui ada tidaknya pengaruh antara variabel independen dengan variabel dependen. Ghozali \& Latan (2012) menjelaskan jika nilai $t$-statistics lebih dari 1,96 (two-tiled) maka hipotesis dapat diterima. 


\section{HASIL DAN PEMBAHASAN}

Dari penyebaran kuesioner yang dilakukan pada April 2020 - Mei 2020, ternyata jumlah responden yang berkontribusi dalam pengisian kuesioner mencapai 184, atau 24 lebih banyak dari jumlah sampel minimal yang dibutuhkan, yaitu sebanyak 160. Karena semuanya memenuhi syarat untuk dianalisis, maka data isian kuesioner dari 184 responden ini semuanya akan disertakan untuk dianalisis. Hasilnya, mayoritas responden dalam penelitian ini merupakan pengguna aplikasi Jogja Istimewa yang berasal dari Jawa Tengah yang sedang merantau untuk sementara waktu di DIY (kos atau semacamnya). Dari segi usia, jenis kelamin, dan pekerjaan, masing-masing responden mayoritas berusia 25-35 tahun, berjenis kelamin laki-laki dan bekerja sebagai karyawan swasta. Lalu, mayoritas responden telah menggunakan layanan online selama 5 tahun atau lebih dan mayoritas responden ternyata belum pernah menggunakan fitur pengajuan informasi publik, E-Lapor maupun E-Ticketing dalam aplikasi Jogja Istimewa. Kemudian dari analisis deskriptif variabel, variabel-variabel pada penelitian ini dinilai dengan melihat nilai rata-rata dan memberi arti pada nilai tersebut dengan membuat kriteria atau kategori berdasarkan interval kelas rata-rata. Durianto et al. (2001) menjelaskan bahwa interval kelas dapat dihitung menggunakan rumus:

Interval $=\frac{\text { Nilai } \text { Tertinggi }- \text { Nilai } \text { Terendah }}{\text { Banyaknya Kelas }}$ sehingga didapatkan hasil: $\quad$ Interval $=\frac{6-1}{6}=0,83$.

Berdasarkan hasil perhitungan diatas, maka didapatkan interval kelas pada setiap skala yang digunakan dan juga kategori tingkat penerimaannya seperti yang bisa dilihat pada Tabel 2.

Tabel 2. Kategori Tingkat Penerimaan

\begin{tabular}{cc}
\hline \hline Interval Kelas & Kategori \\
\hline $1,00 \leq \mathrm{x} \leq 1,83$ & Sangat Buruk \\
$1,84 \leq \mathrm{x} \leq 2,67$ & Buruk \\
$2,68 \leq \mathrm{x} \leq 3,51$ & Cukup Buruk \\
$3,52 \leq \mathrm{x} \leq 4,35$ & Cukup Baik \\
$4,36 \leq \mathrm{x} \leq 5,19$ & Baik \\
$5,20 \leq \mathrm{x} \leq 6,00$ & Sangat Baik \\
\hline
\end{tabular}

Dari hasil analisis deskriptif variabel, dapat diketahui bahwa tingkat penerimaan masyarakat terhadap aplikasi Jogja Istimewa masuk dalam kategori "Cukup Baik", bisa dilihat pada Tabel 3.

Tabel 3. Tingkat Penerimaan terhadap Aplikasi Jogja Istimewa

\begin{tabular}{lcc}
\hline \multicolumn{1}{c}{ Variabel } & Rata-rata & Kategori \\
\hline Performance Expectancy (PE) & 4,65 & Baik \\
Effort Expectancy (EE) & 4,82 & Baik \\
Social Infuence (SI) & 4,47 & Baik \\
Facilitating Conditions (FC) & 4,78 & Baik \\
Habit (HA) & 3,96 & Cukup Baik \\
Trust (TR) & 4,85 & Baik \\
Perceived Risk (PR) & 2,94 & Cukup Buruk \\
Behavior Intention (BI) & 4,36 & Baik \\
Use Behavior (UB) & 4,22 & Cukup Baik \\
\multicolumn{1}{c}{ Total } & 4,34 & Cukup Baik \\
\hline \hline
\end{tabular}

\subsection{Evaluasi Model Pengukuran (Outer Model)}

Untuk uji validitas konvergen, dari hasil pengujian pertama ternyata indikator PR4 dan PR5 tidak memenuhi syarat (skor loading tidak > 0,7) karena jumlah responden yang mengisi dua pertanyaan ini tidak memenuhi jumlah sampel, sehingga dua indikator ini dihilangkan. Oleh karena itu, dilakukan kembali pengecekan ulang terhadap nilai skor loading dari setiap indikatornya dengan tidak menyertakan indikator PR4 dan PR5. Hasilnya, semua indikator sudah mempunyai nilai skor loading $>0,7$ sehingga tahap uji validitas 
konvergen dapat dilanjutkan kembali. Selanjutnya dilakukan pengujian nilai AVE pada setiap konstruk, bisa dilihat pada Tabel 4.

Tabel 4. Nilai AVE

\begin{tabular}{cc}
\hline Konstruk & Nilai AVE \\
\hline PE & 0,766 \\
EE & 0,785 \\
SI & 0,785 \\
FC & 0,648 \\
HA & 0,765 \\
TR & 0,707 \\
PR & 0,643 \\
BI & 0,831 \\
UB & 0,746 \\
\hline \hline
\end{tabular}

Hasilnya menunjukkan, bahwa semua konstruk mempunyai nilai AVE > 0,5, sehingga semua konstruk memenuhi syarat uji validitas konvergen.

Sementara untuk uji validitas diskriminan, hasil perhitungannya menunjukkan bahwa nilai akar kuadrat AVE lebih besar daripada nilai korelasi antar konstruk, seperti yang ditunjukkan pada Tabel 5. Lalu, nilai korelasi antar item dengan konstruknya juga menunjukkan bahwa nilainya lebih tinggi dibandingkan dengan korelasi item tersebut terhadap konstruk lain sehingga semua item telah memenuhi validitas diskriminan. Kemudian untuk uji reliabilitasnya, hasilnya semua variabel dinyatakan reliabel karena semuanya memiliki nilai cronbach's alpha > 0,6 dan juga composite reliability > 0,7, seperti yang ditunjukkn pada Tabel 6 .

Tabel 5. Nilai Akar Kuadrat AVE dan Nilai Korelasi Antar Konstruk

\begin{tabular}{lccccccccc}
\hline & BI & EE & FC & HA & PE & PR & SI & TR & UB \\
\hline BI & $\mathbf{0 , 9 1 2}$ & & & & & & & & \\
EE & 0,616 & $\mathbf{0 , 8 8 6}$ & & & & & & & \\
FC & 0,661 & 0,729 & $\mathbf{0 , 8 0 5}$ & & & & & & \\
HA & 0,700 & 0,485 & 0,516 & $\mathbf{0 , 8 7 5}$ & & & & & \\
PE & 0,705 & 0,685 & 0,639 & 0,645 & $\mathbf{0 , 8 7 5}$ & & & & \\
PR & 0,495 & 0,307 & 0,361 & 0,407 & 0,306 & $\mathbf{0 , 8 0 2}$ & & & \\
SI & 0,735 & 0,622 & 0,669 & 0,680 & 0,731 & 0,445 & $\mathbf{0 , 8 8 6}$ & & \\
TR & 0,553 & 0,555 & 0,583 & 0,466 & 0,519 & 0,174 & 0,488 & $\mathbf{0 , 8 4 1}$ & \\
UB & 0,729 & 0,534 & 0,610 & 0,644 & 0,597 & 0,364 & 0,586 & 0,423 & $\mathbf{0 , 8 6 4}$ \\
\hline \hline
\end{tabular}

Tabel 6. Nilai Cronbach's Alpha dan Composite Reliability

\begin{tabular}{lccl}
\hline \hline Konstruk & $\begin{array}{c}\text { Cronbach's } \\
\text { Alpha }\end{array}$ & $\begin{array}{c}\text { Composite } \\
\text { Reliability }\end{array}$ & Keterangan \\
\hline PE & 0,847 & 0,908 & Reliabel \\
EE & 0,909 & 0,936 & Reliabel \\
SI & 0,863 & 0,917 & Reliabel \\
FC & 0,819 & 0,880 & Reliabel \\
HA & 0,846 & 0,907 & Reliabel \\
TR & 0,860 & 0,906 & Reliabel \\
PR & 0,723 & 0,844 & Reliabel \\
BI & 0,898 & 0,937 & Reliabel \\
UB & 0,832 & 0,898 & Reliabel \\
\hline \hline
\end{tabular}

\subsection{Evaluasi Model Struktural (Inner Model)}

Nilai $R$-Square dibagi menjadi tiga kategori, yaitu kategori tinggi dengan nilai lebih dari 0.75, kategori sedang dengan nilai 0.25 sampai 0.75 , dan kategori rendah dengan nilai kurang dari 0.25 (Ghozali \& Latan, 2015). Untuk nilai $R$-Square-nya bisa dilihat pada Tabel 7. 
Tabel 7. Nilai $R$-Square

\begin{tabular}{lc}
\hline \hline \multicolumn{1}{c}{ Variabel } & $\boldsymbol{R}$-Square \\
\hline Behavior Intention (BI) & 0,701 \\
Use Behavior (UB) & 0,589 \\
\hline \hline
\end{tabular}

Didapatkan bahwa nilai $R$-square dari variabel BI adalah sebesar 0.701 yang berarti bahwa variabel PE, EE, SI, FC, HA, TR, dan PR mempengaruhi variabel BI sebesar $70.1 \%$ dan sisanya sebesar $29.9 \%$ dipengaruhi oleh variabel lain. Sementara itu, variabel UB memiliki nilai $R$-square sebesar 0.589 , yang berarti bahwa variabel FC,HA dan BI mempengaruhi variabel UB sebesar $58.9 \%$ dan sisanya $41.1 \%$ dipengaruhi oleh variabel lain di luar penelitian ini. Lalu untuk mengetahui hasil pengujian hipotesis dengan PLS bisa dilihat pada Tabel 8. Signifikansi dalam perhitungan ini adalah 0.05 (t-hitung > t-tabel 1.96).

Tabel 8. Nilai T-Statistics

\begin{tabular}{llccc}
\hline Hipotesis & Keterangan & T-Statistics & P Values & Keterangan Hipotesis \\
\hline H1 & PE $\rightarrow$ BI & 2,025 & 0,043 & Diterima \\
H2 & EE $\rightarrow$ BI & 0,497 & 0,619 & Ditolak \\
H3 & SI $\rightarrow$ BI & 2,199 & 0,028 & Diterima \\
H4 & FC $\rightarrow$ BI & 1,491 & 0,137 & Ditolak \\
H5 & FC $\rightarrow$ UB & 2,042 & 0,042 & Diterima \\
H6 & HA $\rightarrow$ BI & 3,221 & 0,001 & Diterima \\
H7 & HA $\rightarrow$ UB & 3,081 & 0,002 & Diterima \\
H8 & TR $\rightarrow$ BI & 2,151 & 0,032 & Diterima \\
H9 & PR $\rightarrow$ BI & 3,190 & 0,002 & Diterima \\
H10 & BI $\rightarrow$ UB & 3,627 & 0,000 & Diterima \\
\hline \hline
\end{tabular}

Berdasarkan hasil dari T-Statistics dan P-Value pada Tabel 5, maka hasil analisis terhadap model penelitian yang digunakan bisa dilihat pada Gambar 1.

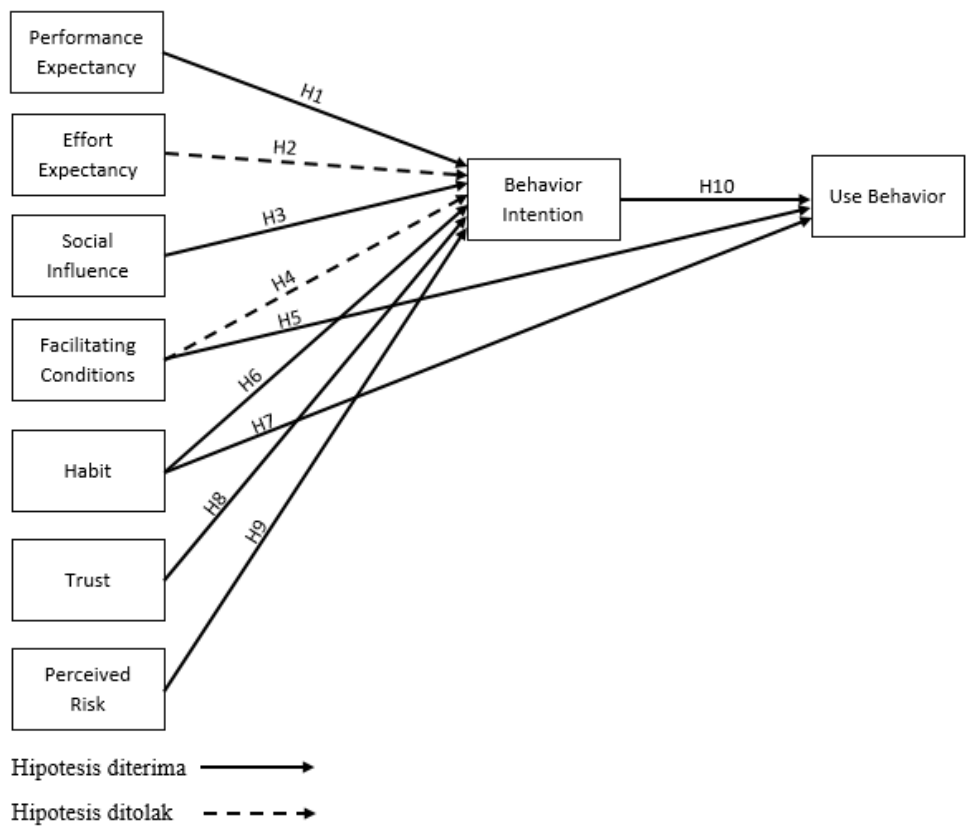

Gambar 1. Hasil Analisis Model Penelitian.

\subsection{PEMBAhaSAN}

Dari Gambar 1, diketahui bahwa terdapat dua (2) hipotesis yang ditolak yaitu $\mathrm{H} 2$ dan $\mathrm{H} 4$ karena kedua hipotesis ini memiliki nilai $T$-Statistics yang kurang dari 1,96 dan nilai $P$-Value yang lebih besar dari 0,05 142 
seperti yang ditunjukkan pada Tabel 5. Sementara H1, H3, H5, H6, H7, H8, H9, H10 semuanya terbukti dan dapat diterima. Terkait terbuktinya $\mathrm{H} 1$, hasil penelitian ini serupa dengan penelitian bidang e-government dari Al Mansoori et al. (2018); Alharbi et al. (2017); Chirara (2018); Sawalha et al. (2019). Sebagian besar responden juga mengatakan bahwa aplikasi ini mampu mempermudah aktivitasnya. Hal itu juga dibuktikan dari hasil perhitungan tingkat penerimaan masyarakat terhadap aplikasi Jogja Istimewa dari segi Performance Expectancy (PE) yang masuk dalam kategori "Baik". Namun, beberapa responden dalam penelitian ini mengatakan bahwa walaupun mereka telah mengunduh aplikasi ini, mereka masih jarang menggunakannya dengan alasan mereka lebih sering mendapatkan informasi-informasi mengenai DIY dari teman dan social media, bukan dari aplikasi Jogja Istimewa. Serupa dengan kasus ini, penelitian dari Rachmawati et al. (2018) juga mengungkapkan bahwa alasan respondennya tidak memanfaatkan aplikasi Jogja Istimewa yaitu karena mereka belum membutuhkan dan sudah mengetahui informasi seputar DIY. Maka dari itu, penting bagi Pemda DIY dan Diskominfo untuk terus memberikan serta menekankan pemahaman terhadap masyarakatnya mengenai pentingnya (manfaat) dari aplikasi Jogja Istimewa. Ditekankan bahwa melakukan aktivitas-aktivitas tertentu dengan menggunakan aplikasi Jogja Istimewa lebih baik daripada melalui cara tradisional.

Terkait tidak terbuktinya $\mathrm{H} 2$, hasil ini bertentangan dengan penelitian dari Lian (2015). Ini mungkin karena penelitian Lian (2015) berfokus pada niat awal atau respondennya belum menggunakan sistem target. Lian (2015) juga menjelaskan bahwa respondennya bukan pengguna, melainkan orang-orang yang berpotensi menjadi pengguna di masa depan. Sementara penelitian ini respondennya adalah orang-orang yang sudah menjadi pengguna aplikasi Jogja Istimewa, sehingga BI atau niat perilaku di UTAUT2 didasarkan pada niat kelanjutan. Penelitian ini juga membuktikan bahwa Habit (HA) mempengaruhi BI (H6). Menurut Alharbi et al. (2017), EE memainkan peran penting dalam inisial niat namun saat warga menjadi terbiasa dengan sistem dan terbiasa menggunakan itu, mereka akan melanjutkan dengan niat untuk menggunakan layanan itu bahkan jika itu menjadi lebih kompleks. Beberapa responden juga tidak mempermasalahkan bahwa aplikasi Jogja Istimewa ini mudah digunakan atau tidak. Hasil perhitungan tingkat penerimaan masyarakat terhadap aplikasi Jogja Istimewa menunjukkan bahwa dari segi Effort Expectancy (PE) sudah masuk dalam kategori "Baik". Komentar-komentar di Google Play Store juga tidak ada yang menyebut bahwa aplikasi Jogja Istimewa ini sulit digunakan. Sehingga, masih belum perlu bagi Pemda DIY untuk meningkatkan penerimaan dari segi EE karena tingkat penerimaan EE sudah baik dan apabila ditingkatkan juga tidak akan mempengaruhi niat masyarakat untuk menggunakan aplikasi Jogja Istimewa. Oleh sebab itu, tidak ada alasan bagi peneliti untuk memberikan rekomendasi terkait dengan Effort Expectancy (EE).

Terkait terbuktinya H3, hasil serupa juga ditunjukkan di beberapa penelitian sebelumnya (e.g.(Alharbi et al., 2017; Chirara, 2018; Lian, 2015; Rabaa'i, 2017; Weerakkody et al., 2013)). Beberapa responden juga mengatakan bahwa mereka meng-install aplikasi Jogja Istimewa karena mereka mendapat informasi dari temannya yang mengatakan bahwa aplikasi Jogja Istimewa merupakan aplikasi yang bagus dan dapat memudahkannya dalam menyelesaikan keperluan di DIY. Hasil perhitungan tingkat penerimaan masyarakat terhadap aplikasi Jogja Istimewa dari segi Social Influence (SI) sudah masuk dalam kategori "Baik". Namun, penelitian dari Rachmawati et al. (2018) mengungkapkan bahwa mayoritas respondennya menyebutkan bahwa mereka tidak mengetahui aplikasi Jogja Istimewa karena belum menerima sosialisasi. Untuk itu, kegiatan sosialisasi masih perlu untuk ditingkatkan karena SI terbukti mempengaruhi niat pengguna untuk menggunakan aplikasi Jogja Istimewa. Pemda DIY juga bisa kembali memperbaiki metode sosialisasinya. Sosialisasi perlu untuk lebih digencarkan dengan berbagai strategi atau pendekatan yang berbeda. Selain meningkatkan intensitas sosialisasi, Pemda DIY juga sebaiknya memikirkan cara yang efektif dalam promosi. Misalnya dengan merancang berbagai kegiatan promosi untuk pengguna yang berbeda. Bisa melalui social media, berita online, TV, baliho, videotron, media koran, dan bisa juga memasang spanduk di setiap kantor pemerintah atau objek wisata.

Terkait tidak terbuktinya H4 dan tebuktinya H5, hasil ini sesuai dengan pernyataan Venkatesh et al. (2003) bahwa ketika baik konstruk PE dan EE disajikan, FC menjadi tidak signifikan dalam memprediksi niat sehingga FC tidak mempunyai pengaruh yang signifikan terhadap BI namun akan langsung mempengaruhi UB. Temuan penelitian ini yang mengungkapkan bahwa FC mempengaruhi UB ini konsisten dengan hasil penelitian e-government sebelumnya (e.g.(Chirara, 2018; Rabaa'i, 2017)). Tingkat penerimaan masyarakat terhadap aplikasi Jogja Istimewa dari segi FC memang sudah masuk dalam kategori "Baik". Namun, masih ada beberapa responden yang beranggapan bahwa fitur CCTV menghabiskan cukup banyak kuota internet, sehingga mereka jarang menggunakan CCTV tersebut kecuali jika terdapat WiFi. Pengguna di kolom komentar Google Play Store juga ada yang mengatakan bahwa public hostpot memang penting. Terkait dengan hal tersebut, Pemda DIY dapat meningkatkan dukungan seperti bantuan akses internet yang bisa dilakukan dengan menambah jumlah area WiFi gratis. Selain itu, Pemda DIY juga dapat memperhatikan ketersediaan sumber daya penggunanya, misalnya tipe smartphones dan OS (Operating System) yang digunakan oleh penggunapenggunanya. Hal itu dikarenakan, beberapa responden merasa bahwa aplikasi Jogja Istimewa merupakan 
aplikasi yang cukup berat dan memakan banyak daya baterai. Ini juga ditunjukkan dalam komentar-komentar pengguna yang ada di kolom komentar Google Play Store yang mengatakan bahwa aplikasi Jogja Istimewa tidak berjalan seperti semestinya di smartphone dan OS tertentu. Maka dari itu, disarankan bagi Pemda DIY untuk dapat memungkinkan aplikasi Jogja Istimewa menjadi aplikasi yang bisa digunakan di berbagai jenis smartphones dan OS.

Terkait terbuktinya H6, hasil ini konsisten dengan hasil penelitian Alharbi et al. (2017) yang mengungkapkan bahwa EE memainkan peran penting dalam inisial niat namun saat warga menjadi terbiasa dalam menggunakan e-government, mereka akan melanjutkan dengan niat untuk menggunakan layanan itu bahkan jika itu menjadi lebih kompleks. Temuan ini juga konsisten dengan penelitian Syamsudin et al. (2018) yang juga dilakukan di Indonesia. Namun, temuan penelitian ini juga mengungkapkan bahwa HA juga langsung mempengaruhi UB (H7 terbukti). Hasil ini juga konsisten dengan penelitian dari Chirara (2018) yang membuktikan bahwa UB dipengaruhi oleh kebiasaan warga (Habit) menggunakan layanan online terlepas dari apakah layanan e-government itu masih menyediakan saluran tradisional atau tidak. Pemda DIY bisa mengambil langkah untuk meningkatkan faktor Habit ini apalagi tingkat penerimaan masyarakat terhadap aplikasi Jogja Istimewa dari segi Habit (HA) hanya masuk dalam kategori "Cukup Baik", belum sampai "Baik". Pemda DIY dan Diskominfo dapat membuat penggunaan Jogja Istimewa menjadi kebiasaan (habit) bagi penggunanya dengan memberikan reward kepada penggunanya. Reward bisa ditunjukkan tidak hanya dengan uang, tapi bisa ditunjukkan dengan cara lain. Beberapa responden menyarankan bahwa ketika pengguna menggunggah foto di fitur galeri foto dengan akun instagramnya, pihak aplikasi Jogja Istimewa bisa re-post atau memposting ulang foto tersebut di akun Instagram Jogja Istimewa dengan menandai (tag) pengguna yang mengunggah foto tersebut. Selain itu, cara lain dalam memberikan reward bisa dengan cara seperti yang disarankan oleh salah satu pengguna yang berkomentar dalam kolom komentar Google Play Store yaitu melibatkan pengguna dalam membuat review, seperti di google maps. Pengguna yg memberikan review diberikan badge.

Terkait terbuktinya H8, mayoritas studi yang menyelidiki dampak Trust pada BI juga menunjukkan bahwa Trust berpengaruh positif terhadap BI. Beberapa penelitian e-government sebelumnya yang konsisten dengan temuan dari penelitian yaitu Albesher (2016); Bélanger \& Carter (2008); Carter \& Bélanger (2005); Lian (2015). Walaupun sebagian responden sudah percaya dengan aplikasi Jogja Istimewa bahkan sudah ditunjukkan dengan tingkat penerimaan masyarakat terhadap aplikasi Jogja Istimewa dari segi Trust (TR) yang masuk dalam kategori "Baik", namun ada juga beberapa yang masih belum merasa benar-benar aman, terutama bagi masyarakat yang belum menggunakan aplikasi Jogja Istimewa. Buktinya, forum tidak resmi ICJ jumlah anggotanya masih jauh lebih banyak dari pengguna aplikasi Jogja Istimewa walaupun aplikasi Jogja Istimewa sudah diluncurkan hampir lima (5) tahun yang lalu. Menurut Larasati (2018), akun ICJ tersebut memang merupakan akun yang dapat dipercaya. Ditambah lagi, salah satu pengguna dalam kolom komentar Google Play Store juga berkomentar bahwa dia tidak mau menggunakan aplikasi Jogja Istimewa ketika aplikasi memerlukan pengguna untuk mengizinkan akses untuk lokasi, kamera dan penyimpanan smartphone-nya. Sehingga, Pemda DIY sebaiknya berupaya untuk meyakinkan masyarakat bahwa aplikasi Jogja Istimewa itu aman dan memberi pemahaman kepada masyarakat tentang pentingnya keamanan informasi dalam kehidupan masyarakat. Ketika calon pengguna sudah menggunakan, harus ada pengamanan untuk memastikan bahwa warga terus menggunakan aplikasi Jogja Istimewa ini. Ini dapat dicapai dengan memastikan bahwa warga mendapat dukungan dan sumber daya yang dibutuhkan untuk terus menggunakan aplikasi Jogja Istimewa.

Terkait terbuktinya H9, Temuan ini konsisten dengan penelitian sebelumnya yang juga membuktikan adanya pengaruh negatif dari PR terhadap BI. Beberapa penelitian tersebut diantaranya Aljazzaf (2019); Carter et al. (2016); Chatzoglou et al. (2015); Dashti et al. (2009); Lian (2015). Faktor PR ini tentunya dapat menjadi bahan pertimbangan bagi Pemda DIY selaku pembuat kebijakan aplikasi Jogja Istimewa sebagai salah satu cara untuk meningkatkan niat perilaku warga terhadap aplikasi Jogja Istimewa apalagi tingkat penerimaan masyarakat terhadap aplikasi Jogja Istimewa dari segi Perceived Risk (PR) ini masuk dalam kategori "Cukup Buruk". Pemda DIY bisa selalu memelihara aplikasi dan perangkat-perangkat yang terhubung dengan aplikasi, sehingga ketika mendapati bahwa salah satu fungsi aplikasi tidak berjalan dengan semestinya, maka dapat segera diperbaiki. Ini penting, karena banyak komentar pengguna di kolom komentar Google Play Store yang mengindikasan bahwa pemeliharaan aplikasi Jogja Istimewa cenderung kurang baik. Cara lainnya yaitu dengan meningkatkan dukungan dengan merespon setiap keluhan pengguna yang ditujukan terhadap aplikasi Jogja Istimewa di kolom review google play store. Setiap keluhan tersebut juga harus ditindaklanjuti supaya tidak menimbulkan persepsi negatif terhadap pengguna tersebut atau pengguna lainnya atau calon pengguna. Memang, sebagian besar komentar sudah dibalas bahkan ditindaklanjuti oleh Pemda DIY. Namun, masih ada beberapa komentar yang bahkan belum direspon. Sehingga, perlu bagi Pemda DIY untuk terus meningkatkan 
dukungan dengan merespon setiap keluhan pengguna yang ditujukan terhadap aplikasi Jogja Istimewa di kolom review google play store.

Terkait terbuktinya H10, temuan ini juga konsisten dengan penelitian-penelitian layanan e-government sebelumnya (e.g.(Al Mansoori et al., 2018; Chirara, 2018; Rabaa'i, 2017)). Selain itu, pengujian H10 ini mempunyai nilai $t$-statistics yang terbesar dan nilai $p$-value yang terendah dibandingkan dengan hasil uji hipotesis-hipotesis lainnya dalam penelitian ini, sehingga bisa dikatakan bahwa Behavior Intention (BI) merupakan faktor terkuat dari Use Behavior (UB). Temuan ini konsisten dengan argumen teoritis UTAUT dari Venkatesh et al. (2003) yang menyatakan bahwa niat perilaku sebagai prediktor kuat dari perilaku penggunaan.

\section{PENUTUP}

\subsection{Kesimpulan}

Tingkat penerimaan warga terhadap aplikasi Jogja Istimewa masuk dalam kategori “Cukup Baik”. Oleh karena itu, penerimaan aplikasi Jogja Istimewa perlu ditingkatkan lagi agar bisa menjadi "Baik" atau bahkan menjadi "Sangat Baik".Faktor-faktor yang mempengaruhi variabel Use Behavior dari yang paling signifikan adalah Behavior Intention (BI), diikuti Habit (HA) dan Facilitating Conditions (FC). Faktor-faktor yang mempengaruhi variabel Behavior Intention (BI) yang merupakan prediktor terkuat dari variabel Use Behavior (UB) dari yang paling signifikan adalah Habit (HA), kemudian Perceived Risk (PR), Social Influence (SI), Trust (TR) dan Performance Expectancy (PE).Terdapat dua (2) faktor yang tidak mempengaruhi Behavior Intention (BI) yaitu Facilitating Conditions (FC) Effort Expectancy (EE).

\subsection{Saran Untuk Pembuat Kebijakan}

Beberapa rekomendasi yang ditawarkan oleh peneliti di antaranya adalah:

1. Pemda DIY dapat merancang berbagai kegiatan promosi untuk pengguna yang berbeda. Bisa melalui social media, berita online, baliho, videotron, TV, media koran, atau spanduk yang dipasang di tempattempat tertentu seperti di setiap objek wisata, atau kantor pemerintahan.

2. Metode sosialisasinya bisa diperbaiki dan lebih digencarkan lagi dengan berbagai strategi atau pendekatan yang berbeda.

3. Memberikan dan menekankan pemahaman terhadap masyarakatnya mengenai pentingnya penggunaan aplikasi Jogja Istimewa. Ditekankan bahwa melakukan aktivitas-aktivitas tertentu menggunakan aplikasi Jogja Istimewa lebih baik daripada melalui cara tradisional. Cara ini bisa dilakukan ketika sedang melakukan kegiatan sosialisasi atau promosi.

4. Meyakinkan warga bahwa aplikasi Jogja Istimewa aman dan memberi pemahaman kepada masyarakat tentang pentingnya keamanan informasi dalam kehidupan masyarakat. Cara ini juga bisa dilakukan ketika sedang melakukan kegiatan sosialisasi atau promosi.

5. Harus ada pengamanan untuk memastikan warga terus menggunakan aplikasi Jogja Istimewa. Ini dicapai dengan memastikan bahwa warga mendapat dukungan dan sumber daya yang dibutuhkan untuk terus menggunakan aplikasi Jogja Istimewa.

6. Selalu memelihara aplikasi sehingga ketika mendapati bahwa salah satu fungsi aplikasi tidak berjalan dengan semestinya, maka bisa segera diperbaiki.

7. Meningkatkan dukungan dengan merespon setiap keluhan pengguna yang ditujukan terhadap aplikasi Jogja Istimewa di review google play store. Setiap keluhan tersebut juga harus ditindaklanjuti supaya tidak menimbulkan persepsi negatif terhadap pengguna tersebut atau pengguna-pengguna lainnya.

8. Meningkatkan ketersediaan sumber daya dengan menambah jumlah area wifi gratis.

9. Memungkinkan aplikasi Jogja Istimewa untuk bisa digunakan di berbagai smartphones dan OS.

10. Memberikan reward kepada penggunanya. Misalnya, ketika pengguna menggunggah foto di fitur galeri foto dengan akun instagramnya, pihak aplikasi Jogja Istimewa bisa re-post atau memposting ulang foto tersebut di akun Instagram Jogja Istimewa dengan menandai ( $\mathrm{tag}$ ) pengguna yang mengunggah foto tersebut. Bisa juga melibatkan pengguna dalam membuat review objek tempat-tempat wisata atau budaya atau kantor pemerintahan dan sebagainya seperti di aplikasi Google Maps. Pengguna yang memberikan review diberikan badge.

\subsection{Keterbatasan Penelitian}

Penelitian ini tentunya memiliki beberapa keterbatasan. Beberapa keterbatasannya yaitu:

1. Hasil penelitian ini tidak dapat digeneralisasi pada aplikasi-aplikasi travel \& local lainnya karena aplikasi-aplikasi travel \& local lainnya sebagian besar bukan dikembangkan dari pihak pemerintah serta tidak terdapat layanan e-government-nya seperti aplikasi Jogja Istimewa.

2. Seperti yang ditunjukkan pada hasil $R$-Square, masih ada faktor-faktor di luar penelitian ini yang tidak teridentifikasi pada penelitian ini yang bisa mempengaruhi variabel Use Behavior. 
3. Penelitian ini tidak bisa membuktikan bahwa variabel PR dapat diukur menggunakan indikator Security/Privacy Risk dan Financial Risk karena jumlah responden yang menjawab pertanyaanpertanyaan yang mewakili kedua indikator tersebut tidak mencapai jumlah minimal sampel yang ditentukan.

4. Hasil pengujian hipotesis menunjukkan bahwa variabel EE dan FC tidak mempengaruhi BI padahal banyak penelitian sebelumnya yang membuktikan sebaliknya.

5. Penelitian ini tidak menguji keterkaitan antar variabel eksogennya sehingga penelitian ini tidak bisa mengidentifikasi apakah ada pengaruh antar variabel eksogen atau tidak

\subsection{Saran Untuk Penelitian Selanjutnya}

Beberapa saran untuk penelitian selanjutnya di antaranya yaitu:

1. Dapat mengeksplorasi lebih jauh variabel-variabel yang tidak teridentifikasi dalam penelitian ini untuk melihat bagaimana penerimaan masyarakatnya terhadap layanan e-government.

2. Dapat mengeksplorasi lebih jauh variabel PR yang menggunakan indikator Security/Privacy Risk dan Financial Risk untuk lebih menunjukkan hasil yang lebih komprehensif terkait dengan pengukuran pengaruh dari variabel PR terhadap BI.

3. Dapat mengeksplorasi lebih jauh mengenai variabel FC dan EE misalnya dengan menambah jumlah sampel yang jauh lebih banyak dari jumlah sampel dalam penelitian ini.

4. Dapat menguji keterkaitan antar variabel-variabel eksogen yang ada dalam penelitian ini. Misalnya, menguji apakah Trust (TR) berpengaruh terhadap Perceived Risk (PR) atau sebaliknya.

\section{DAFTAR RUJUKAN}

Abdillah, W., \& Hartono, J. (2015). Partial Least Square (PLS) Alternatif Structural Equation Modeling (SEM) dalam Penelitian Bisnis. Penerbit Andi.

Ajzen, I. (1991). The theory of planned behavior. Organizational Behavior and Human Decision Processes, 50(2), 179-211. https://doi.org/10.4135/9781446249215.n22

Al Mansoori, K. A., Sarabdeen, J., \& Tchantchane, A. L. (2018). Investigating Emirati citizens' adoption of egovernment services in Abu Dhabi using modified UTAUT model. Information Technology \& People. https://doi.org/10.1108/ITP-12-2016-0290

Albesher, A. (2016). Trust as a source of long-term adoption of e-government. In Doctoral dissertation, Brunel University London. http://dspace.brunel.ac.uk/handle/2438/12368

Alharbi, N., Papadaki, M., \& Dowland, P. (2017). The impact of security and its antecedents in behaviour intention of using e-government services. Behaviour and Information Technology, 36(6), 620-636. https://doi.org/10.1080/0144929X.2016.1269198

Aljazzaf, Z. M. (2019). Evaluating trust in E-government: The case of Kuwait. Proceedings of the 2019 5th International Conference on Computer and Technology Applications, 140-144. https://doi.org/10.1145/3323933.3324073

Bélanger, F., \& Carter, L. (2008). Trust and risk in e-government adoption. The Journal of Strategic Information Systems, 17(2), 165-176.

Bentler, P. M., \& Chou, C.-P. (1987). Practical issues in structural modeling. Sociological Methods \& Research, 16(1), 78-117. https://doi.org/10.1177/0049124187016001004

Carter, L., \& Bélanger, F. (2005). The utilization of e-government services: citizen trust, innovation and acceptance factors. Information Systems Journal, 15(1), 5-25.

Carter, L., Shaupp, L. C., Hobbs, J., \& Campbell, R. (2011). The role of security and trust in the adoption of online tax filing. Transforming Government: People, Process and Policy, 5(3), 303-318. http://dx.doi.org/10.1108/17506161111173568

Carter, L., Weerakkody, V., Phillips, B., \& Dwivedi, Y. K. (2016). Citizen Adoption of E-Government Services: Exploring Citizen Perceptions of Online Services in the United States and United Kingdom. Information Systems Management, 33(2), 124-140. https://doi.org/10.1080/10580530.2016.1155948

Chatzoglou, P., Chatzoudes, D., \& Symeonidis, S. (2015). Factors affecting the intention to use e-Government services. Proceedings of the 2015 Federated Conference on Computer Science and Information Systems, FedCSIS 2015, 5, 1489-1498. https://doi.org/10.15439/2015F171

Chin, W. W. (1998). The Partial Least Squares Approach to Structural Equation Modeling. In Modern Method for Business Research (pp. 295-336). Lawrence Erlbaum Associates Inc.

Chirara, S. (2018). Social inclusion: an e-government approach to access social welfare benefits [Doctoral dissertation, Nottingham Trent University]. http://irep.ntu.ac.uk/id/eprint/35355/

Dashti, A., Benbasat, I., \& Burton-Jones, A. (2009). Developing trust reciprocity in electronic government: 
The role of felt trust. Proceedings of the European and Mediterranean Conference on Information Systems.

Durianto, D., Sugiarto, \& Sitinjak, T. (2001). Strategi menaklukkan pasar melalui riset ekuitas dan perilaku konsumen. Gramedia.

Fornell, C., \& Larcker, D. F. (1981). Evaluating Structural Equation Models with Unobservable and Measurement Error. Journal of Marketing Research, 18(1), 39-50.

Ghozali, I. (2006). Structural Equation Modeling Metode Alternatif dengan PLS (Edisi 2). BP Undip.

Ghozali, I. (2007). Aplikasi Analisis Multivariate Dengan Program SPSS. Badan Penerbit Universitas Diponegoro.

Ghozali, I., \& Latan, H. (2012). Partial Least Squares : Konsep, Teknik dan Aplikasi Menggunakan Program SmartPLS 2.0 M3. Badan Penerbit Universitas Diponegoro.

Ghozali, I., \& Latan, H. (2015). Partial Least Squares: Konsep, Teknik dan Aplikasi Menggunakan SmartPLS 3.0 untuk penelitian empiris (Edisi). Universitas Diponegoro.

Hair, J. F., Black, W. C., Babin, B. J., \& Anderson, R. E. (2009). Multivariate Data Analysis 7th Edition Pearson Prentice Hal. https://doi.org/10.2307/1266874

Krishnaraju, V., Mathew, S. K., \& Sugumaran, V. (2013). Role of web personalization in consumer acceptance of E-government services. 19th Americas Conference on Information Systems, AMCIS 2013 Hyperconnected World: Anything, Anywhere, Anytime, 4, 2911-2918.

Lallmahomed, M. Z. I., Lallmahomed, N., \& Lallmahomed, G. M. (2017). Factors influencing the adoption of e-Government services in Mauritius. Telematics and Informatics, 34(4), 57-72. https://doi.org/10.1016/j.tele.2017.01.003

Larasati, B. (2018). Tingkat Kepercayaan Followers terhadap Informasi di Akun Facebook (ICJ) Info Cegatan Jogja. 1, 1-18.

Lee, M. C. (2009). Factors influencing the adoption of internet banking: An integration of TAM and TPB with perceived risk and perceived benefit. Electronic Commerce Research and Applications, 8(3), 130-141. https://doi.org/10.1016/j.elerap.2008.11.006

Lian, J.-W. (2015). Critical factors for cloud based e-invoice service adoption in Taiwan: An empirical study. International Journal of Information Management, $35(1), \quad 98-109$. https://doi.org/10.1016/j.ijinfomgt.2014.10.005

Martono, N. (2010). Metode Penelitian Kuantitatif, Analisis Isi dan Analisis Data Sekunder. PT. Raya Grafindo Persada.

Mayer, R. C., Davis, J. H., \& Schoorman, F. D. (1995). An Integrative Model of Organizational Trust. Academy of Management Review, 20(3), 709-734. https://doi.org/10.5465/AMR.1995.9508080335

Mcknight, D. H., Choudhury, V., \& Kacmar, C. (2002). Developing and Validating Trust Measures for eCommerce : An Integrative Typology. Information Systems Research, 13(3), 334-359.

Munyoka, W. (2019). Exploring the Factors Influencing e-Government use: Empirical Evidence from Zimbabwe. The Electronic Journal of Information Systems Evaluation, 22(2), $78-91$. https://doi.org/10.34190/EJISE.19.22.2.002

Plimbi Editor. (2015). Mau Liburan ke Bandung? Manfaatkan Aplikasi Android Hi Bandung!

Rabaa'i, A. A. (2017). The use of UTAUT to investigate the adoption of E-government in Jordan: A cultural perspective. International Journal of Business Information Systems, 24(3), 285-315. https://doi.org/10.1504/IJBIS.2017.10002806

Rachmawati, R., Ramadhan, E. R., \& Rohmah, A. 'Ainur. (2018). Aplikasi Smart Province "Jogja Istimewa": Penyediaan Informasi Terintegrasi dan Pemanfaatannya. Majalah Geografi Indonesia, 32(1), 14-23. https://doi.org/10.22146/mgi.31662

Robert, L. P., Denis, A. R., \& Hung, Y.-T. C. (2009). Individual swift trust and knowledge-based trust in faceto-face and virtual team members. Journal of Management Information Systems, 26(2), 241-279. https://doi.org/10.2753/MIS0742-1222260210

Sawalha, S., Al-Jamal, M., \& Abu-Shanab, E. (2019). The influence of utilising Facebook on e-government adoption. Electronic Government, 15(1), 1-20. https://doi.org/10.1504/EG.2019.096573

Sekaran, U., \& Bougie, R. (2006). Research methods for business. Salemba Empat

Shareef, M. A., Kumar, V., Kumar, U., \& Dwivedi, Y. K. (2011). E-Government Adoption Model (GAM): Differing service maturity levels. Government Information Quarterly, 28(1), 17-35. https://doi.org/10.1016/j.giq.2010.05.006

Singh, N., Sinha, N., \& Liébana-Cabanillas, F. J. (2020). Determining factors in the adoption and recommendation of mobile wallet services in India: Analysis of the effect of innovativeness, stress to use and social influence. International Journal of Information Management, 50, 191-205. https://doi.org/10.1016/j.ijinfomgt.2019.05.022 
Syamsudin, Meiyanti, R., Satria, D., Wahyuni, R., \& Sensuse, D. I. (2018). Exploring factors influence behavioral intention to use E-government services using unified theory of acceptance and use of technology 2 (UTAUT2). 2018 International Seminar on Research of Information Technology and Intelligent Systems, ISRITI 2018, 2, 237-242. https://doi.org/10.1109/ISRITI.2018.8864474

Taylor, S., \& Todd, P. A. (1995). Understanding information technology usage: A test of competing models. Information Systems Research, 6(2), 144-176. https://doi.org/10.1287/isre.6.2.144

Venkatesh, V., Morris, M. G., Davis, G. B., \& Davis, F. D. (2003). User acceptance of information technology: Toward a unified view. MIS Quarterly, 27, 425-478. https://doi.org/10.1016/j.inoche.2016.03.015

Venkatesh, V., Thong, J. Y. L., Chan, F. K. Y., Hu, P. J.-H., \& Brown, S. A. (2011). Extending the two-stage information systems continuance model: Incorporating UTAUT predictors and the role of context. Information Systems Journal, 21(6), 527-555. https://doi.org/10.1111/j.1365-2575.2011.00373.x

Venkatesh, V., Thong, J. Y. L., \& Xu, X. (2012). Consumer Acceptance and Use of Information Technology: Extending the Unified Theory of Acceptance and Use of Technology. MIS Quarterly, 36(1), 157-178. https://pdfs.semanticscholar.org/6256/0e2001480fd1f22558ce4d34ac93776af3e6.pdf\%0Ahttps://pdfs.s emanticscholar.org/6256/0e2001480fd1f22558ce4d34ac93776af3e6.pdf?_ga=2.124539978.199417976 4.1540339706-2125081534.1540339706

Weerakkody, V., El-Haddadeh, R., Al-Sobhi, F., Shareef, M. A., \& Dwivedi, Y. K. (2013). Examining the influence of intermediaries in facilitating e-government adoption: An empirical investigation. International Journal of Information Management, 33(5), 716-725. https://doi.org/10.1016/j.ijinfomgt.2013.05.001 